University of Nebraska - Lincoln

DigitalCommons@University of Nebraska - Lincoln

\title{
Avian Paramyxovirus Serotype 1 (Newcastle Disease Virus), Avian Influenza Virus, and Salmonella spp. in Mute Swans (Cygnus olor) in the Great Lakes Region and Atlantic Coast of the United States
}

\author{
Kerri Pedersen \\ USDA APHIS Wildlife Services, Kerri.Pedersen@aphis.usda.gov \\ David R. Marks \\ Dustin M. Arsnoe \\ Claudio L. Afonso \\ Sarah N. Bevins \\ USDA APHIS Wildlife Services, Sarah.N.Bevins@aphis.usda.gov
}

See next page for additional authors

Follow this and additional works at: https://digitalcommons.unl.edu/icwdm_usdanwrc

Part of the Life Sciences Commons

Pedersen, Kerri; Marks, David R.; Arsnoe, Dustin M.; Afonso, Claudio L.; Bevins, Sarah N.; Miller, Patti J.; Randall, Adam R.; and DeLiberto, Thomas J., "Avian Paramyxovirus Serotype 1 (Newcastle Disease Virus), Avian Influenza Virus, and Salmonella spp. in Mute Swans (Cygnus olor) in the Great Lakes Region and Atlantic Coast of the United States" (2014). USDA National Wildlife Research Center - Staff Publications. 1410.

https://digitalcommons.unl.edu/icwdm_usdanwrc/1410

This Article is brought to you for free and open access by the U.S. Department of Agriculture: Animal and Plant Health Inspection Service at DigitalCommons@University of Nebraska - Lincoln. It has been accepted for inclusion in USDA National Wildlife Research Center - Staff Publications by an authorized administrator of DigitalCommons@University of Nebraska - Lincoln. 


\section{Authors}

Kerri Pedersen, David R. Marks, Dustin M. Arsnoe, Claudio L. Afonso, Sarah N. Bevins, Patti J. Miller, Adam R. Randall, and Thomas J. DeLiberto 


\title{
Avian Paramyxovirus Serotype 1 (Newcastle Disease Virus), Avian Influenza Virus, and Salmonella spp. in Mute Swans (Cygnus olor) in the Great Lakes Region and Atlantic Coast of the United States
}

\author{
Author(s): Kerri Pedersen , David R. Marks, Dustin M. Arsnoe, Claudio L. Afonso, Sarah N. Bevins , \\ Patti J. Miller, Adam R. Randall, and Thomas J. DeLiberto \\ Source: Avian Diseases, 58(1):129-136. 2014. \\ Published By: American Association of Avian Pathologists \\ DOI: http://dx.doi.org/10.1637/10638-081413-Reg.1 \\ URL: http://www.bioone.org/doi/full/10.1637/10638-081413-Reg.1
}

BioOne (www.bioone.org) is a nonprofit, online aggregation of core research in the biological, ecological, and environmental sciences. BioOne provides a sustainable online platform for over 170 journals and books published by nonprofit societies, associations, museums, institutions, and presses.

Your use of this PDF, the BioOne Web site, and all posted and associated content indicates your acceptance of BioOne's Terms of Use, available at www.bioone.org/page/terms_of_use.

Usage of BioOne content is strictly limited to personal, educational, and non-commercial use. Commercial inquiries or rights and permissions requests should be directed to the individual publisher as copyright holder. 


\title{
Avian Paramyxovirus Serotype 1 (Newcastle Disease Virus), Avian Influenza Virus, and Salmonella spp. in Mute Swans (Cygnus olor) in the Great Lakes Region and Atlantic Coast of the United States
}

\author{
Kerri Pedersen, ${ }^{\mathrm{AF}}$ David R. Marks, ${ }^{\mathrm{B}}$ Dustin M. Arsnoe, ${ }^{\mathrm{B}}$ Claudio L. Afonso, ${ }^{\mathrm{C}}$ Sarah N. Bevins, ${ }^{\mathrm{D}}$ Patti J. Miller, ${ }^{\mathrm{C}}$ \\ Adam R. Randall, ${ }^{\mathrm{E}}$ and Thomas J. DeLiberto ${ }^{\mathrm{A}}$

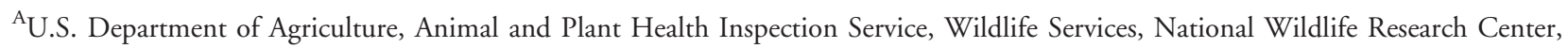 \\ 4101 LaPorte Avenue, Fort Collins, CO 80521 \\ ${ }^{B}$ U.S. Department of Agriculture, Animal and Plant Health Inspection Service, Wildlife Services, 2803 Jolly Road, Suite 100, Okemos, MI 48864 \\ ${ }^{C}$ U.S. Department of Agriculture, Agricultural Research Service, Southeast Poultry Research Laboratory, 934 College Station Road, \\ Athens, GA 30605 \\ ${ }^{\mathrm{D}}$ Colorado State University, Department of Biomedical Sciences, Campus Delivery 1683, 3107 Rampart Road, Fort Collins, CO 80523 \\ ${ }^{\text {E}}$ U.S. Department of Agriculture, Animal and Plant Health Inspection Service, Wildlife Services, 140-C Locust Grove Road, Pittstown, NJ 08867
}

Received 21 August 2013; Accepted 15 November 2013; Published ahead of print 15 November 2013

\begin{abstract}
SUMMARY. Since their introduction to the United States in the late 19th century, mute swans (Cygnus olor) have become a nuisance species by causing damage to aquatic habitats, acting aggressively toward humans, competing with native waterfowl, and potentially transmitting or serving as a reservoir of infectious diseases to humans and poultry. In an effort to investigate their potential role as a disease reservoir and to establish avian health baselines for pathogens that threaten agricultural species or human health, we collected samples from 858 mute swans and tested them for avian paramyxovirus serotype 1 (APMV-1), avian influenza virus (AIV), and Salmonella spp. when possible. Our results indicate that exposure to APMV-1 and AIV is common $(60 \%, n=$ 771 , and $45 \%, n=344$, antibody prevalence, respectively) in mute swans, but detection of active viral shedding is less common $(8.7 \%, n=414$, and $0.8 \%, n=390$, respectively). Salmonella was isolated from three mute swans $(0.6 \%, n=459)$, and although the serovars identified have been implicated in previous human outbreaks, it does not appear that Salmonella is commonly carried by mute swans.
\end{abstract}

RESUMEN. Paramixovirus aviar serotipo 1 (virus de la enfermedad de Newcastle), virus de influenza aviar y Salmonella spp. en cisnes comunes (Cygnus olor) de la Región de los Grandes Lagos y en la costa atlántica de los Estados Unidos.

Desde su introducción a los Estados Unidos a finales del siglo 19, los cisnes comunes (Cygnus olor) se han convertido en una especie problemática, porque causa daños a los hábitats acuáticos, actuando agresivamente hacia los seres humanos, compite con las aves acuáticas nativas, y potencialmente puede transmitir o servir como reservorio de enfermedades infecciosas para los seres humanos y para las aves comerciales. En un esfuerzo por investigar su posible papel como reservorios de la enfermedad y para establecer líneas base de salud aviar para los patógenos que amenazan a las especies agrícolas o a la salud humana, se recolectaron muestras de 858 cisnes comunes y se analizaron para detectar paramixovirus aviar serotipo 1 (APMV- 1), virus de la influenza aviar (AIV) y Salmonella spp. cuando fue posible. Los resultados indican que la exposición a APMV -1 y al virus de influenza aviar es común en cisnes comunes $(60 \%, n=771, \mathrm{y} 45 \%, n=344$, para la prevalencia de anticuerpos, respectivamente), pero la detección de la replicación viral activa es menos común $(8.7 \%, n=414$, y $0.8 \%, \mathrm{n}=390$, respectivamente). Se aisló Salmonella de tres cisnes comunes $(0.6 \%, \mathrm{n}=459)$, y aunque los serovares identificados han sido implicados en brotes humanos anteriores, no parece que la Salmonella sea acarreada comúnmente por los cisnes comunes.

Key words: avian influenza virus, avian paramyxovirus serotype 1, Cygnus olor, mute swan, Newcastle disease virus, Salmonella

Abbreviations: AIV = avian influenza virus; APMV-1 = avian paramyxovirus serotype 1; bELISA = blocking enzyme-linked immunosorbent assay; $\mathrm{BHI}=$ brain heart infusion; $\mathrm{CL}=$ confidence limits; $\mathrm{HA}=$ hemagglutination assay; $\mathrm{HI}=$ hemagglutination inhibition; HPAIV = highly pathogenic avian influenza virus; ICPI = intracerebral pathogenicity index; LPAIV = low pathogenic avian influenza virus; $M D T=$ mean death time; $M S U=$ Michigan State University; NDV = Newcastle disease virus; NVSL = National Veterinary Services Laboratories; PI = percent inhibition; rRT-PCR $=$ real-time reverse transcriptase polymerase chain reaction; SEPRL $=$ Southeast Poultry Research Laboratory; $S / N=$ sample to negative; SPF $=$ specific-pathogen-free; USDA $=$ United States Department of Agriculture; USGS = United States Geological Survey; WS = Wildlife Services

Mute swans (Cygnus olor) were first introduced for their aesthetic value to the Atlantic Coast of the United States in the late 19th century. Since then, feral populations of mute swans have become established sporadically across the United States, and annual population surveys indicate an alarming increase in their populations, particularly in areas along the Atlantic Coast and Great Lakes $(30,32)$. As mute swan populations continue to grow, their geographic distribution is also expanding (5). Their complacency

\footnotetext{
${ }^{\mathrm{F}}$ Corresponding author. E-mail: Kerri.Pedersen@aphis.usda.gov
}

toward humans, longevity, and ability to adapt to a wide variety of habitats including rivers, lakes, ponds, and brackish marshes (10) have resulted in a significant increase in their population. Excessive numbers of mute swans can remove bank vegetation, resulting in shoreline erosion and an increase in sedimentation in lakes, ponds, and reservoirs. An individual swan can consume up to eight pounds of submerged aquatic vegetation daily (50), resulting in adverse impacts on wetlands (47) including up to a $95 \%$ reduction in biomass of submerged aquatic vegetation (5). Although mute swans eat a considerable amount of vegetation, they also uproot vegetation that they do not eat, leading to the further destruction of plant mass 
(7). This excessive depletion of submerged aquatic vegetation can also lead to competition with native waterfowl for food and resources $(4,38)$.

Mute swans exhibit territorial behavior toward other birds, which has contributed to declines in native bird numbers (49). In Michigan specifically, mute swans outcompete the state-threatened trumpeter swan (Cygnus buccinator) in nesting areas and have negatively impacted the trumpeter swan recovery program (33). In addition to killing trumpeter swans while defending their territory, mute swans begin nesting earlier in the year, which may interfere with successful trumpeter swan nesting (22).

Mute swans also present a hazard to human health and safety because of their aggressive behavior toward humans during the nesting season. A territorial mute swan is credited with the drowning of a kayaker in Illinois on April 12, 2012. In addition to physical attack, there is also potential for fecal contamination of water sources by mute swans in areas with high human recreational use. Although some studies have examined specific cases of disease in mute swans, we sought to establish baselines for agricultural and/or zoonotic pathogens of interest on a much larger geographic and quantitative scale than has been conducted previously to more fully assess the role of mute swans as vectors of disease.

Avian paramyxovirus serotype 1. One of the viruses identified for examination was avian paramyxovirus serotype 1 (APMV-1), also referred to as Newcastle disease virus (NDV), because it infects and causes disease in both wild and domestic birds (29). The virus can cause mortality or be asymptomatic depending on the virulence of the strain and the resistance of the host that is infected (1). Most of the 200 bird species that have been reported as infected do not exhibit any clinical signs; however, a virulent NDV infection in unvaccinated poultry may result in up to $100 \%$ mortality. In waterfowl, virulence varies with the strain of APMV-1 and the susceptibility of the host species and their immunity; however, mortality caused by virulent viruses is typically lower than poultry (25). Virulent NDV infection in species such as cormorants $(13,28)$, and feral pigeons (26) has resulted in large-scale mortality events and spillover into other species such as pelicans (52) and gulls (15). The primary concern in the United States is the introduction of virulent NDV into poultry facilities, which often results in mandatory destruction of the entire flock to contain the outbreak. This makes NDV one of the most economically important diseases for poultry production (2). Very little is known about the incidence of APMV-1 in wild birds except that nearly all species are susceptible (23), and a large diversity and wide distribution of low-pathogenicity viruses across different geographic regions exist in waterfowl and shorebirds (25). More recently, evidence has been presented that suggests the potential for intercontinental spread of APMV-1 by wild birds (39). APMV-1 antibodies have been reported in mute swans previously (16); however, relatively small sample sizes and limited geographic distribution were examined.

Avian influenza virus. Wild birds are the natural reservoir of avian influenza virus (AIV), and highly pathogenic AIV (HPAIV) specifically is of concern because it can cause morbidity and mortality in humans, wild birds, and domestic birds. Although HPAIV is not endemic in North America, the virus has resulted in large-scale die-offs in poultry (21) and certain species of wild birds $(9,48)$, in addition to human mortality $(11)$ in other countries. In Europe, mute swans have been identified as important vectors of AIV (21). Not only are mute swans highly susceptible to HPAIV, but their size and color render them easy to detect when mortality occurs (21), suggesting that they are good epidemiologic sentinels (48). There is concern that low pathogenic avian influenza, specifically $\mathrm{H} 5$ and $\mathrm{H} 7$ subtypes, may become highly pathogenic after introduction into poultry (34). Thus, characterization of the subtypes carried by mute swans as well as the apparent prevalence of both AIV virus and antibodies are important for better understanding the epidemiology of the virus in this species. Since exposure history affects transmission dynamics, determination of the prevalence of low pathogenic avian influenza virus (LPAIV) in mute swans may provide insight into the percentage of mute swans that would be afforded immunity to HPAIV if it were introduced into the United States. It also might be used to clarify whether AIV is, or could become, endemic in the resident mute swan populations in the United States, thus serving as a regular source of infection for other birds.

Salmonella. Salmonellae are enteric bacteria that can cause disease in animals and humans. Most serotypes are not host specific (14), leading to abundant transmission opportunities both within and between species. Chickens, ducks, and geese are known hosts of Salmonella spp., and the likelihood of human contact with infected domestic birds is typically higher compared to wild bird species. Salmonella has been documented previously in mute swans $(12,44)$, and as mute swan populations continue to increase in urban and recreational areas of the United States, the potential for fecal contamination and subsequent transmission to humans is elevated.

Objectives. Mute swans are actively managed in the Great Lakes region and along the Atlantic Coast because their growing population numbers have led to a significant amount of damage to aquatic habitat, competition with native waterfowl, and human conflicts. The U.S. Department of Agriculture (USDA), Animal and Plant Health Inspection Service, Wildlife Services (WS), works to mitigate damage to property, agriculture, and natural resources caused by mute swans in conjunction with state wildlife agencies. As a part of this management effort, we opportunistically sampled mute swans for various pathogens including APMV-1, AIV, and Salmonella spp. with the objective of establishing baseline avian health data and evaluating the potential role mute swan populations may play in the epidemiology of a variety of diseases of concern in regard to agricultural species or human health.

\section{MATERIALS AND METHODS}

Sample collection. Mute swans were sampled in Michigan, New Jersey, Rhode Island, New York, Indiana, Wisconsin, and Massachusetts, USA, from March 2011 through September 2012. The number of sampling locations and time of year that samples were collected varied by state. Mute swans were lethally removed by WS following the American Veterinary Medical Association Guidelines on Euthanasia (6). All samples were collected post mortem within $2 \mathrm{hr}$ of death.

Approximately $10 \mathrm{ml}$ of blood was collected from each swan by making a small cut in the jugular vein and then lowering the head below the body to allow blood to flow into the collection tube. The tube was labeled with a unique barcode and then transferred to a cooler with ice packs. Blood was centrifuged at $1500 \mathrm{rpm}$ for $15 \mathrm{~min}$, and then $\geq 1 \mathrm{ml}$ of serum was transferred to a $2 \mathrm{ml}$ cryogenic vial. Serum was stored refrigerated at $4 \mathrm{C}$ until shipping within 3 days of collection.

Cloacal and oropharyngeal swabs were collected from each bird using sterile polyester-tipped swabs (Puritan ${ }^{\circledR}$, Puritan Medical Products Company, Guilford, ME). Swabs from individual birds were combined in a single cryogenic vial with a unique barcode containing $3 \mathrm{ml}$ of brain heart infusion broth (BHI; Becton Dickinson and Co., Sparks, MD) and were immediately transferred to a cooler with ice packs. Swabs were left in the sample vial after collection and were stored frozen at $-80 \mathrm{C}$ until testing. The BHI medium was prepared and distributed by the USDA National Veterinary Services Laboratories (NVSL) in Ames, Iowa. 
An additional cloacal swab was collected using the BBL CultureSwab collection and transport system (Becton Dickinson) that contained Amies Liquid Medium, Liquid Stuart Medium, and Cary-Blair Transport Medium. It was labeled with a bird-specific barcode and kept cool until shipping within 3 days of collection.

Collection site information including county, state, and global positioning system coordinates in WGS84 was recorded on a standardized data sheet, which also included bird-specific information and individually unique barcodes.

Testing: APMV-1. Serology. A blocking ELISA (bELISA) (Svanova Biotech AB, Uppsala, Sweden, or ID VET Montpellier, France) was used by Michigan State University (MSU) to detect the presence of APMV-1 antibodies in 771 samples according to the manufacturer's instructions and using multiple positive and negative controls. Percent inhibition (PI) values greater than $40 \%$ were considered positive, whereas PI values less than $30 \%$ were considered negative. PI values between $30 \%$ and $40 \%$ were considered undetermined, and the samples were retested once.

Virus detection and isolation. Swab samples were forwarded to the USDA's Southeast Poultry Research Laboratory (SEPRL) in Athens, GA, for APMV-1 testing. The matrix real-time reverse transcriptase polymerase chain reaction (rRT-PCR) assay, which targets the M gene, was used to screen the 414 samples (54). Since this assay does not detect $70 \%$ of class I low-virulence APMV-1s, the multiplex rRT-PCR assay, which targets the L gene, was run as well (27). RNA extraction was calculated as previously described by Diel et al. (15).

Swab medium from each APMV-1 PCR positive sample was inoculated into three 9-to-11-day-old specific-pathogen-free (SPF) embryonating chicken eggs using standard methods as previously described by Senne (40). All isolates were identified, subtyped, and characterized according to standard procedures at the SEPRL.

Intracerebral pathogenicity index (ICPI) assay. One-day-old SPF chicks were inoculated intracerebrally with $50 \mu \mathrm{l}$ of a 1:10 dilution of viral infected allantoic fluid, monitored daily for 8 days, and scored as 0 if normal, 1 if sick, or 2 if dead. The ICPI value was calculated as the mean score per bird per observation (3).

Hemagglutination assay. The hemagglutination assay (HA) was completed using microtiter methods. The HA of allantoic fluids harvested from inoculated embryonating eggs was used to identify APMV-1-positive embryos. Known APMV-1 positive serum was used for the micro-beta hemagglutination inhibition (HI) assay to that confirm HA activity was due to APMV-1.

Mean death time (MDT). Nine-to-11-day-old SPF embryonating chicken eggs were inoculated with viral-infected allantoic fluid as described previously (3). The viral-infected allantoic fluids were collected from the inoculated eggs either after the death of the embryo or after 6 days postinoculation and were titrated by HA using the Spearmann-Karber method to calculate the $\operatorname{EID}_{50}$ (24). MDT over $90 \mathrm{hr}$ was expected for low-virulence APMV-1.

Amplification and sequencing. Extracted RNA from viral-infected fluid was extracted and then converted to cDNA by reverse transcription and amplified using PCR. This larger amount of cDNA was used to sequence the virus. Amplification of the RNA and sequencing of the complete coding region of the fusion gene was performed according to methods previously described by Kim et al. (27).

Phylogenetic analysis. A 374 base pair and full fusion region of the F gene was used to construct the phylogenetic trees and to phylogenetically classify the mute swan NDV isolates $(n=2)$ because the highest percentage nucleotide corresponded to a partial GenBank sequence. This was conducted according to methods previously described by Diel et al. (15). The evolutionary history was inferred by using the maximum likelihood method based on the general time reversible model (15). The tree with the highest log likelihood $(-10,190.6466)$ is shown (Fig. 1). The percentage of trees in which the associated taxa clustered together is shown next to the branches. Initial trees for the heuristic search were obtained automatically by applying Neighbor-Join and BioNJ algorithms to a matrix of pairwise distances estimated using the maximum composite likelihood method, and then selecting the topology with superior log likelihood value. A discrete Gamma distribution was used to model evolutionary rate differences among sites (4 categories; $+\mathrm{G}$, parameter $=1.7362)$. The rate variation model allowed for some sites to be evolutionarily invariable $([+\mathrm{I}], 45.0285 \%$ sites). The tree is drawn to scale, with branch lengths measured in the number of substitutions per site. The analysis involved 117 nucleotide sequences because this was the number of nucleotides of the most closely related sequence available in GenBank. Codon positions included were 1 st $+2 \mathrm{nd}+3 \mathrm{rd}+$ Noncoding. There were a total of 1662 positions in the final data set. Evolutionary analyses were conducted in MEGA5 (46).

Accession numbers. The sequences of the F gene of the APMV-1 isolates characterized in this study are available in GenBank under accession numbers KF444680 and KF444681.

AIV. Serology. All serum samples were tested for the presence of AIV antibodies using a multispecies bELISA (IDEXX Laboratories, Westbrook, ME) according to the manufacturer's instructions and using multiple positive and negative controls. Sample-to-negative $(\mathrm{S} / \mathrm{N})$ ratios $<0.50$ were considered positive, whereas those $\geq 0.50$ were considered negative.

Virus detection and isolation. Swab samples were thawed at $37 \mathrm{C}$ and homogenized by vortexing. RNA extractions were performed using the QIAamp viral RNA mini kit (Qiagen Sciences, Germantown, MD) using $140 \mu \mathrm{l}$ of sample material, according to the manufacturer's instructions. The 390 samples were initially screened by rRT-PCR for the AIV matrix gene at MSU following protocols described by Spackman et al. (43). Matrix-positive samples were further tested with $\mathrm{H} 5$ - and $\mathrm{H} 7$-specific assays $(41,43)$. Virus isolation was conducted on all matrix positive samples at the NVSL by inoculating a suspension of each specimen into embryos of SPF chicken eggs (45).

Salmonella detection. Samples were submitted to MSU for Salmonella culture and serogrouping. Specimens were selectively enriched in tetrathionate brilliant green broth with $36 \mu \mathrm{l}$ in $9 \mathrm{ml}$ of iodine (per sample) and incubated at $42 \mathrm{C}$. At $24 \mathrm{hr}, 100 \mu \mathrm{l}$ of culture was transferred to $10 \mathrm{ml}$ of Rappaport-Vissiliadis broth and incubated for $1824 \mathrm{hr}$ at $37 \mathrm{C}$. Cultures were then inoculated onto two agar plates selective for Salmonella growth (brilliant green agar with novobiocin and xylose-lysine-tergitol-4 agar) and incubated for 18-24 hr at $37 \mathrm{C}$. If nonlactose fermenting colonies were observed, five morphologically distinct colonies with typical characteristics of Salmonella enterica organisms were selected from either of the two agar plates, inoculated onto triple sugar iron agar slant and lysine iron agar slant, and incubated at $37 \mathrm{C}$ for $18-24 \mathrm{hr}$ to identify reactions typical of S. enterica. If reactions were typical of $S$. enterica, no further testing was necessary. Presumptive positive isolates were confirmed as necessary with Vitek Legacy GNI+ cards (BioMerieux, Durham, NC). All positives were identified by standard methods. Each isolate was serotyped by slide agglutination with antisera specific for Salmonella $\mathrm{O}$ groups and tube agglutination for flagellar $(\mathrm{H})$ antigens. Serotyping of isolates based on the Kauffman-White classification scheme was performed at MSU by standard methods. Isolates where serotyping was incomplete were forwarded to the Michigan Department of Community Health for further testing.

Data analysis. Mean seroprevalence and 95\% confidence limits were determined using an exact binomial distribution for prevalence of both pathogens. Co-infection relationships between individuals that were actively infected with both AIV and APMV-1 were determined using Fisher's exact test.

\section{RESULTS}

From March 2011 to September 2012, we collected samples from 858 mute swans in Indiana, Massachusetts, Michigan, New Jersey, New York, Rhode Island, and Wisconsin (Table 1). The majority of the samples $(85 \%)$ were collected from after-hatch-year birds. A total of 771 mute swans were submitted for APMV-1 antibody testing, 414 for APMV-1 viral detection, 344 for AIV antibody testing, 390 for AIV virus detection, and 459 samples for Salmonella testing (Table 1). There were 527 mute swans that were tested for 


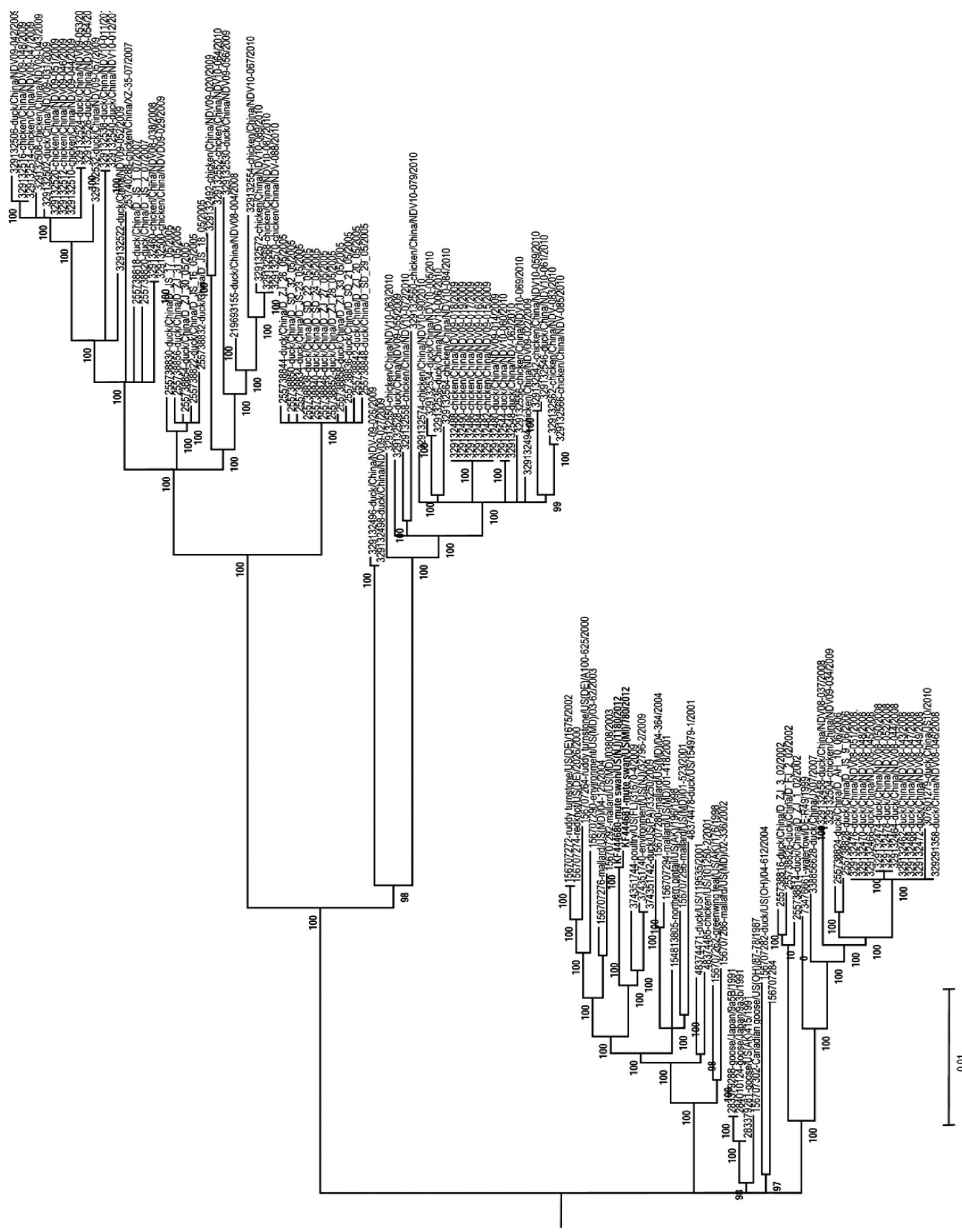

章

政

월

훙

की

웡

范

जै छ

घี 즐

ธี ปี

.

芑

प्च

$\vec{\square} \cdot \exists$

릉 ?

要

들

인.

일

ठ․

营家

寻宁

둼

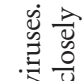

Tे

定究

戈

I

丁 $\begin{aligned} & 4 \\ & 0 \\ & 0\end{aligned}$

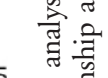

홍.

营

들

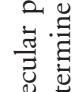

造

28

赔部 
Table 1. Apparent prevalence of avian influenza virus and Newcastle disease virus in mute swans (Cygnus olor) in selected states in the United States as detected by rRT-PCR (swabs) and ELISA (serum).

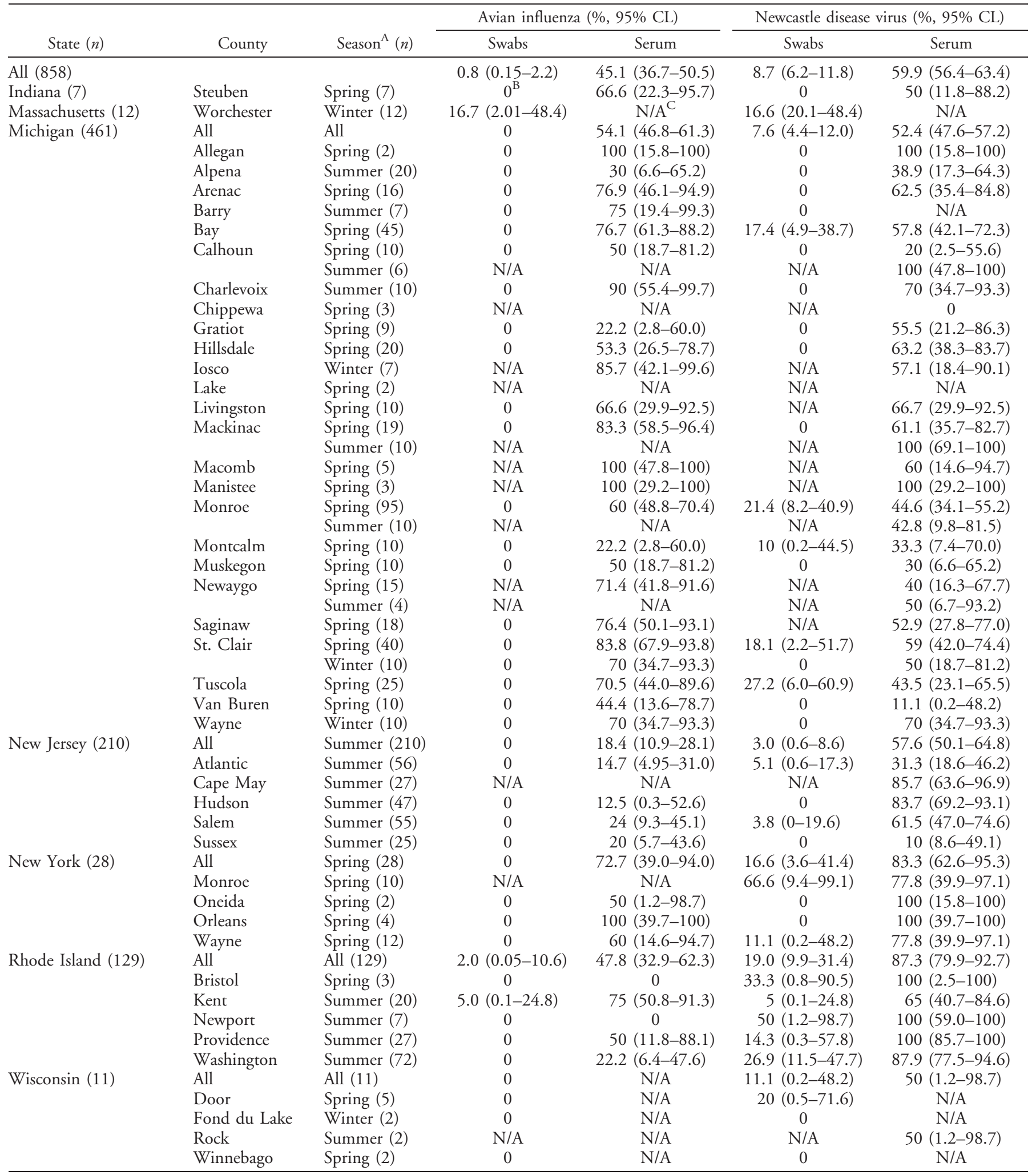

\footnotetext{
${ }^{\mathrm{A}}$ Spring is defined as March through May, summer is defined as June through August, and winter is defined as December through February. No
} samples were collected from September through November.

${ }^{\mathrm{B}}$ Samples were submitted, but none of them tested positive.

${ }^{\mathrm{C}}$ No samples were submitted for testing. 
antibodies to both APMV-1 and AIV. The apparent prevalence of active APMV-1 infection based on rRT-PCR was $8.7 \%(n=414$ $95 \%$ confidence limits [CL]: 6.2-11.8) and the seroprevalence was $59.9 \%(n=771 ; 95 \%$ CL: $56.4-63.4)$. Of 36 APMV-1 viruspositive samples, 25 were seropositive, 6 were seronegative, and 5 were not tested due to insufficient serum. The apparent prevalence of active AIV infection based on rRT-PCR was $0.8 \%(n=390$; 95\% CL: $0.15-2.2)$, and the seroprevalence was $45.1 \%(n=344$; 95\% CL: 36.7-50.5). Serum was available for testing only 1 of the 3 AIV virus positive, samples and it was also antibody positive. No AIV viruses were isolated, and none of the samples were positive by rRT-PCR for the $\mathrm{H} 5$ or $\mathrm{H} 7$ subtype.

Two low-virulence APMV-1 viruses were isolated, and these were subjected to phylogenetic analysis to determine the evolutionary distances to other APMV-1 strains (Fig. 1). Both viruses were class I; however, one of the mute swans was collected in Atlantic County, NJ, in August, and the other was collected in Tuscola County, MI, in April. The nearest related isolates are the viruses G/2009/US/OR/ 374351754 (partial sequence not shown), G/2001/US/48374471, G/2001/US/48374485, G/2009/US/FL/374351744, G/2009/US/ PA/374351742, and G/2009/US/NJ/374351740 (Fig. 1). The ICPI for both isolates was 0.00 , and MDT was $>168 \mathrm{hr}$.

In 2011 a total of 459 samples were tested for Salmonella, and three of them tested positive. Two of the culture positive samples were collected in New Jersey, and one was collected in Rhode Island. The sample from Rhode Island was identified to the species level as $S$. enterica serovar Typhimurium. Strain typing revealed this isolate was negative for the antibiotic-resistant Salmonella Typhimurium DT104. One of the positive samples from New Jersey was identified as Salmonella enterica serovar Braenderup, but the other positive sample was identified only as Group B. Further identification was not possible because the serotype combination is unnamed. Salmonella testing was discontinued in 2012 because so few positives were identified in 2011.

\section{DISCUSSION}

Serologic evidence of NDV has been detected previously in swans (16); however, this previous detection was in aviculturist flocks while our samples were collected from wild birds. Our serosurvey indicated nearly $60 \%$ of mute swans were antibody positive for APMV-1, suggesting that they may be an important reservoir host for APMV-1 or help maintain the virus in the environment. Consequently, they may serve as a risk to poultry that come into contact with them, especially domestic fowl and turkeys that utilize common water sources. Poultry workers and backyard poultry owners whose recreational activities overlap with areas utilized by mute swans also may serve as mechanical vectors of APMV-1 to their flock.

Our data suggest that mute swans in New York and Rhode Island are more likely to be exposed to APMV-1. However, the time of year that samples were collected varied by state, making it difficult to identify any definitive patterns of exposure, and the mechanism for maintenance of APMV-1 in the environment is not fully understood (20).

Age-related immunity is one explanation for our detection of serological evidence of AIV and APMV-1 as significant since most of our samples were collected from after-hatch-year birds, allowing adequate time for exposure and development of antibodies to the viruses. Since sample collection was not distributed evenly across space and time, we are unable to determine whether co-infections are more likely in certain areas.

Our results not only indicate that mute swans are exposed to APMV-1 regularly, but also suggest that active viral infection is not uncommon since almost 9\% of all swans tested were PCR positive, and the majority of samples collected $(98.6 \%)$ were from apparently healthy birds. Although 9\% were APMV-1 positive, we were able to isolate only two viruses. Interestingly, the two full fusion sequences (1662 base pairs) were very similar to each other (99.99\% identity) despite the fact the mute swans were collected in Michigan and New Jersey, thus suggesting that this particular lineage of virus may be more adapted to replicate in swans, or that the virus was recently transported between the two locations by some unknown means (e.g., migrating waterfowl). Since mute swans are nonmigratory birds (37), it is unlikely that the virus moved between locations via mute swans. However, the distance they travel and the amount of commingling between subpopulations is unknown.

The most closely related relatives to our isolates were viruses isolated from wild birds, except for one isolate from a chicken and the other from an unspecified species of poultry (Fig. 1). The identification of sequences so closely related to isolates of poultry origin suggests that there may be spillover among wild birds and poultry, although it is difficult to determine which direction. Also, the viruses may have spilled over more than once based on the different dates of isolation of the poultry isolates (2001 and 2009). Spillover from poultry to wild bird species has been documented (17), and our study suggests that either mute swans may have become infected as a result of spillover from other species or they may represent a reservoir of the virus. It appears that there is very little geographic or evolutionary divergence not only because the mute swan samples we were able to isolate and sequence were from Michigan and New Jersey, but also because the isolates in GenBank with geographic data that were most closely related to our mute swan isolates originated from Oregon, Florida, Pennsylvania, and New Jersey from 2001 to 2009.

Large-scale surveillance efforts to identify AIVs in wild birds in the United States have indicated that mute swans are carriers of LPAIV (35). Specifically, of 2797 samples collected from mute swans, $0.4 \%$ were positive for $\mathrm{H} 5 \mathrm{~N} 1, \mathrm{H} 5 \mathrm{~N} 2$, or H7N3 (USDAWS, unpublished data), all of which are subtypes associated with disease in humans or poultry $(11,36,42)$, and was higher than the $0.2 \%$ of all subtypes from all species found in the 283,434 samples tested nationwide (USDA-WS, unpublished data). Results from our study suggest it is not uncommon for mute swans to be exposed to AIV ( $45.1 \%$ antibody prevalence); however, active viral shedding was less common $(0.8 \%$; 95\% CL: $0.15-2.2)$. Also, two of the three AIV virus-positive samples in our study were collected from mute swans from the same location and day during a morbidity/mortality event of unknown cause. This artificially inflated the apparent prevalence, suggesting that active viral infection in mute swans is relatively uncommon in the areas we sampled. Mute swans are nonmigratory in the United States and consequently are not subject to the same physiological demands placed on migratory birds (53), which could explain the lower prevalence of active viral infection. However, if the virus became established as endemic in a resident population such as mute swans, this would be disconcerting due to the implications for direct and indirect transmission to other birds or humans.

We detected two serovars of Salmonella, both of which are in the top 20 most frequently reported serovars associated with human cases in the United States (8). Detection of Salmonella Typhimurium was of particular interest because it has been identified as a significant cause of food poisoning and enteric fever in humans (31) and is responsible for the majority of salmonellosis in cattle (14). This strain was DT104 negative, which is not surprising since it is unlikely that mute swans would be carrying an antibiotic-resistant 
strain of Salmonella. Salmonella Braenderup is typically an uncommon serotype in the United States; however, it has been documented in human cases that were traced back to consumption of infected chickens, eggs, and tomatoes (19). Even though the third Salmonella positive sample could not be identified beyond Group B, this finding is still significant because some of the Salmonella serotypes most pathogenic to humans are included in Group B, including Salmonella Typhimurium and Salmonella Paratyphi (18).

Our results suggest that as mute swan populations continue to expand their geographic distribution, the potential for disease transmission will also increase since AIV and APMV-1 antibodies were common and active viral infections for both diseases were detected. Since the poultry industry in the United States is worth more than $\$ 38$ billion (51), and these viruses can infect poultry, biosecurity measures to prevent contact in conjunction with additional studies to identify other pathogens of interest are recommended.

\section{REFERENCES}

1. Alexander, D. J. Newcastle disease and other avian paramyxoviruses. Rev. Sci. Tech. 19:443-462. 2000.

2. Alexander, D. J., and D. A. Senne. Newcastle disease, other avian paramyxoviruses, and pneumovirus infections. In: Diseases of poultry, 12th ed. Y. M. Saif, A. M. Fadly, J. R. Glisson, L. R. McDougald, L. K. Nolan, and D. E. Swayne, eds. Iowa State University Press, Ames, IA. pp. 75-100. 2008.

3. Alexander, D. J., and D. A. Senne. Newcastle disease and other avian paramyxoviruses. In: A laboratory manual for the isolation, identification, and characterization of avian pathogens, 5th ed. L. Dufour-Zavala, D. E. Swayne, J. R. Glisson, J. E. Pearson, W. M. Reed, M. W. Jackwood, and P. R. Woolcock, eds. American Association of Avian Pathologists, Athens, GA. pp. 135-141. 2008.

4. Allin, C. C., G. C. Chasko, and T. P. Husband. Mute swans in the Atlantic flyway: a review of the history population growth and management needs. Trans. Northeast Fish Wild. Conf. 4:32-47. 1987.

5. Allin, C. C., and T. P. Husband. Mute swan (Cygnus olor) impact on submerged aquatic vegetation and macroinvertebrates in a Rhode Island coastal pond. Northeast Nat. 10:305-318. 2003.

6. American Veterinary Medical Association. AVMA guidelines for the euthanasia of animals: 2013 edition. AVMA, Schaumburg, IL. 2013.

7. Bailey, M., S. A. Petrie, and S. S. Badzinski. Diet of mute swans in lower Great Lakes coastal marshes. J. Wild. Manage. 72:726-731. 2007.

8. [CDC] Centers for Disease Control. Salmonella surveillance summary, 2003. U.S. Department of Health and Human Services, Atlanta, GA. pp. 1-2. 2004.

9. Chen, H., G. J. D. Smith, S. Y. Zhang, K. Qin, J. Wang, K. S. Li, R. G. Webster, J. S. M. Peiris, and Y. Guan. H5N1 virus outbreak in migratory waterfowl. Nature 436:191-192. 2005.

10. Ciaranca, M. A., C. C. Allin, and G. S. Jones. Mute swan (Cygnus olor). Account 273. In: A. Poole, and F. Gill, eds. The birds of North America. Academy of Natural Sciences, Philadelphia, and American Ornithologists Union, Washington, DC. 1997.

11. Claas, E. C. J., A. D. M. E. Osterhaus, R. van Beek, J. C. De Jong, G. F. Rimmelzwaan, D. A. Senne, S. Krauss, K. F. Shortridge, and R. G. Webster. Human influenza A H5N1 virus related to a highly pathogenic avian influenza virus. Lancet 351:472-476. 1998.

12. Clegg, F. G., and A. E. Hunt. Salmonella infection in mute swans (Cygnus olor). Vet. Rec. 97:373. 1975.

13. Cross, T. A., D. M. Arsnoe, R. B. Minnis, D. T. King, S. Swafford, K. Pedersen, and J. C. Owen. Prevalence of avian paramyxovirus 1 and avian influenza virus in double-crested cormorants (Phalacrocorax auritus) in eastern North America. J. Wild. Dis. 49:965-977. 2013.

14. Daniels, E. K., N. E. Woollen, J. S. Dickson, and E. T. Littledike. Beef cattle salmonellosis: a study of oral S. typhimurium and topical S. newport inoculations. Bovine Pract. 71:168-170. 1993.
15. Diel, D. G., P. J. Miller, P. C. Wolf, R. M. Mickley, A. R. Musante, D. C. Emanueli, K. J. Shively, K. Pedersen, and C. L. Afonso. Characterization of Newcastle disease viruses isolated from cormorant and gull species in the United States in 2010. Avian Dis. 56:128-133. 2012.

16. Friend, M., and D. O. Trainer. Serologic evidence of Newcastle disease in captive mallards and swans. J. Wild. Dis. 6:130-135. 1970.

17. Garcia, S. C., R. N. Lopez, R. Morales, M. A. Olvera, M. A. Marquez, R. Merino, P. J. Miller, and C. L. Afonso. Epidemiological and phylogenetic characterization of Newcastle disease viruses isolated from exotic, wild and commercial birds in Mexico between 2008 and 2011. Appl. Environ. Microbiol. 79:1-8. 2013.

18. García del Portillo, F. Molecular and cellular biology of Salmonella pathogenesis. In: Microbial foodborne diseases: mechanisms of pathogensis and toxin synthesis. J. W. Cary, J. E. Linz, and D. Bhatnagar, eds. Technomic Publishing Company, Lancaster, PA. pp. 3-49. 2000.

19. Gupta, S. K., K. Nalluswami, C. Snider, M. Perch, M. Balasegaram, D. Burmeister, J. Lockett, C. Sandt, R. M. Hoekstra, and S. Montgomery. Outbreak of Salmonella Braenderup infections associated with Roma tomatoes, northeastern United States, 2004: a useful method for subtyping exposures in field investigations. Epidemiol. Infect. 135:1165-1173. 2007.

20. Hanson, B. A., D. E. Swayne, D. A. Senne, D. S. Lopries, J. Hurst, and D. E. Stallknecht. Avian influenza viruses and paramyxoviruses in wintering and resident ducks in Texas. J. Wild. Dis. 41:624-628. 2005.

21. Hars, J., S. Ruette, M. Benmergui, C. Fouque, J.-Y. Fournier, A. Legouge, M. Cherbonnel, B. Daniel, C. Dupuy, and V. Jestin. The epidemiology of the highly pathogenic $\mathrm{H} 5 \mathrm{~N} 1$ avian influenza in mute swan (Cygnus olor) and other Anatidae in the Dombes region (France), 2006. J. Wild. Dis. 44:811-823. 2008.

22. Johnson, J. W. Observations of territorial conflict between trumpeter swans and mute swans in Michigan. In: Proc. and Papers of the Trumpeter Swan Society Conference 16:134-136. 1999.

23. Kaleta, E. F., and C. Baldauf. Newcastle disease in free-living and pet birds. In: Newcastle disease. D. J. Alexander, ed. Kluwer Academic Publishers, Boston. pp. 197-246. 1988.

24. Karber, G. 50\% end-point calculation. Arch. Exp. Pathol. Pharmak. 162:480-183. 1931.

25. Kim, L. M., D. J. King, P. E. Curry, D. L. Suarez, D. E. Swayne, D. E. Stallknecht, R. D. Slemons, J. C. Pedersen, D. A. Senne, K. Winker, and C. L. Afonso. Phylogenetic diversity among low-virulence Newcastle disease viruses from waterfowl and shorebirds and comparison of genotype distributions to those of poultry-origin isolates. J. Virol. 81:12641-12653. 2007.

26. Kim, L. M., D. J. King, H. Guzman, R. B. Tesh, A. P. A. Travassos da Rosa, R. Bueno, Jr., J. A. Dennett, and C. L. Afonso. Biological and phylogenetic characterizations of pigeon paramyxovirus serotype 1 circulating in wild North American pigeons and doves. J. Clin. Microbiol. 46:3303-3310. 2008.

27. Kim, L. M., D. L. Suarez, and C. L. Afonso. Detection of a broad range of class I and II Newcastle disease viruses using a multiplex real-time reverse transcription polymerase chain reaction assay. J. Vet. Diagn. Invest. 20:414-425. 2008.

28. Kuiken, T. Review of Newcastle disease in cormorants. J. Waterbird Soc. 22:333-502. 1999.

29. Leighton, F. A., and R. A. Heckert. Newcastle disease and related avian paramyxoviruses. In: Infectious diseases of wild birds. N. J. Thomas, D. B. Hunter, and C. T. Atkinson, eds. Blackwell Publishing, Ames, IA. pp. 3-16. 2007.

30. Maryland Department of Natural Resources Wildlife and Heritage Service. Mute swans in Maryland: a statewide management plan [Internet]. 2003 [modified 2003 April 14; cited 2013 August 1]. Available from: http:// www.dnr.state.md.us/irc/docs/00014261.pdf.

31. McLelland, M., K. E. Sanderson, J. Spieth, S. W. Clifton, P. Latreille, L. Courtney, S. Porwollik, J. Ali, M. Dante, F. Du, S. Hou, D. Layman, S. Leonard, C. Nguyen, K. Scott, A. Holmes, N. Grewal, E. Mulvaney, E. Ryan, H. Sun, L. Florea, W. Miller, T. Stoneking, M. Nhan, R. Waterston, and R. K. Wilson. Complete genome sequence of Salmonella enterica serovar Typhimurium LT2. Nature 413:852-856. 2001.

32. Michigan Department of Natural Resources. Mute swan issues in Michigan. Wildlife Issue Review Paper 12. pp. 1-10. 2013. Available from: 
http://www.michigan.gov/documents/dnr/mute_swan_issue_paper_June_30_ 2003_364890_7.pdf

33. Michigan Department of Natural Resources. Mute swan management and control program policy and procedures [Internet]. 2012 [modified 2012 Jan 30; cited 2013 Aug 1]. Available from: www.michigan.gov/ documents/dnr/2012_Mute_Swan_Policy_378701_7.pdf.

34. Munster, V. J., and R. A. M. Fouchier. Avian influenza virus: of virus and bird ecology. Vaccine 27:6340-6344. 2009.

35. Pedersen, K., S. R. Swafford, and T. J. DeLiberto. Low pathogenicity avian influenza subtypes isolated from wild birds in the United States, 20062008. Avian Dis. 54:405-410. 2010.

36. Peiris, J. S., M. D. de Jong, and Y. Guan. Avian influenza virus (H5N1): a threat to human health. Clin. Microbiol. Rev. 20:243-267. 2007.

37. Perry, M. C., ed, Mute swans and their Chesapeake Bay habitats: proceedings of a Symposium. U.S. Geological Survey, Biological Resources Discipline Information and Technology Report USGS/BRD/ITR-20040005. USGS, Reston, VA. 60 pp. 2004.

38. Petrie, S. A. Mute swans make noise: lower Great Lakes population scrutinized. Birding 34:34-36. 2002.

39. Ramey, A. M., A. B. Reeves, H. Ogawa, H. S. Ip, K. Imai, V. N. Bui, E. Yamaguchi, N. Y. Silko, and C. L. Afonso. Genetic diversity and mutation of avian paramyxovirus serotype 1 (Newcastle disease virus) in migratory birds and evidence for intercontinental spread. Arch. Virol. 158:2495-2503. 2013.

40. Senne, D. Virus propagation in embryonating eggs. In: A laboratory manual for the isolation, identification and characterization of avian pathogens, 5th ed. L. Dufour-Zavala, ed. American Association of Avian Pathologists, Jacksonville, FL. pp. 204-208. 2008.

41. Spackman, E., H. S. Ip, D. L. Suarez, R. D. Slemons, and D. E. Stallknecht. Analytical validation of a real-time reverse transcription polymerase chain reaction test for pan-American lineage $\mathrm{H} 7$ subtype avian influenza viruses. J. Vet. Diagn. Invest. 20:612-616. 2008.

42. Spackman, E., K. G. McCracken, K. Winker, and D. E. Swayne. $\mathrm{H} 7 \mathrm{~N} 3$ avian influenza virus found in a South American wild duck is related to the Chilean 2002 poultry outbreak, contains genes from equine and North American wild bird lineages, and is adapted to domestic turkeys. J. Virol. 80:7760-7764. 2006.

43. Spackman, E., D. A. Senne, T. J. Myers, L. L. Bulaga, L. P. Garber, M. L. Perdue, K. Lohman, L. T. Daum, and D. L. Suarez. Development of real-time reverse transcriptase PCR assay for type A influenza virus and the avian $\mathrm{H} 5$ and $\mathrm{H} 7$ hemaggluttinin subtypes. J. Clin. Microbiol. 40:3256-3260. 2002.

44. Speckmann, G. Investigation of the occurrence of salmonellae in mute swans (Cygnus olor). Canadian Vet. J. 16:174-175. 1975.

45. Swayne, D. E., D. A. Senne, and C. W. Beard. Avian influenza. In: A laboratory manual for the isolation and identification of avian pathogens. D. E. Swayne, ed. American Association of Avian Pathologists, Kennett Square, PA. pp. 150-155. 1998.

46. Tamura, K., D. Peterson, N. Peterson, G. Stecher, M. Nei, and S. Kumar. MEGA5: molecular evolutionary genetics analysis using maximum likelihood, evolutionary distance, and maximum parsimony methods. Mol. Biol. Evol. 28:2731-2739. 2011.

47. Tatu, K. S., J. T. Anderson, L. J. Hindman, and G. Seidel. Mute swans' impact on submerged aquatic vegetation in Chesapeake Bay. J. Wild. Manage. 71:1431-1439. 2006.

48. Teifke, J. P., R. Klopfleisch, A. Globig, E. Starick, B. Hoffmann, P. U. Wolf, M. Beer, T. C. Mettenleiter, and T. C. Harder. Pathology of natural infections by $\mathrm{H} 5 \mathrm{~N} 1$ highly pathogenic avian influenza virus in mute (Cygnus olor) and whooper (Cygnus cygnus) swans. Vet. Pathol. 44:137-143. 2007.

49. Therres, G., and D. Brinker. Mute swan interaction with other birds in Chesapeake Bay. In: Mute swans and their Chesapeake Bay habitats: proceedings of a symposium. M. C. Perry, ed. U.S. Geological Survey, Biological Resources Discipline Information and Technology Report USGS/ BRD/ITR-2004-0005, Reston, VA. pp. 43-46. 2004.

50. Twining, J. E. Mute swans of the Atlantic coast. Dutch Island Press, Wickford, RI. 1987.

51. USDA, National Agricultural Statistics Service. Poultry-Production and Value 2012. Summary. 2013. Available from: http://usda01.library. cornell.edu/usda/current/PoulProdVa-04-29-2013.pdf

52. USGS. Newcastle Disease. In: Field manual of wildlife diseases: general field procedures and diseases of birds. M. J. Friend, C. Franson, and E. A. Ciganovich, eds. Biological Resources Division Information and Technology Report 1999-001. USGS, Washington, DC. pp. 175-179. 1999.

53. Weber, T. P., and N. I. Stilianakis. Ecologic immunity of avian influenza (H5N1) in migratory birds. Emerg. Infect. Dis. 13:1139-1143. 2007.

54. Wise, M. G., D. L. Suarez, B. S. Seal, J. C. Pedersen, D. A. Senne, D. J. King, D. R. Kapczynski, and E. Spackman. Development of a real-time reverse-transcription PCR for detection of Newcastle disease virus RNA in clinical samples. J. Clin. Microbiol. 42:329-338. 2004.

\section{ACKNOWLEDGMENTS}

We give special thanks to the Wildlife Services' National Wildlife Disease Program wildlife disease biologists and other Wildlife Services employees and state wildlife agency employees in each of the participating states that collected all of the samples to make this project possible. We also thank the numerous technicians and diagnosticians involved in testing these samples, without whom we would not have had results to analyze. The authors would like to acknowledge the excellent work and technical collaboration of Dawn Williams-Coplin and Tim Olivier of the SEPRL. Funding for a portion of the field sample collection and testing efforts was provided by the USFWS, through an interagency agreement (APHIS-WS: 12-7226-4861-IA) as part of their Avian Health and Disease Program. A portion of the Newcastle disease virus section of this research was funded by USDA_ARS CRIS project number 66612-32000-064. Mention of trade names or commercial products in this work is solely for the purpose of providing specific information and does not imply recommendation or endorsement by the U.S. Department of Agriculture. 